Tomasz Janusz Wach*

Lublin

\title{
Krzywda i przebaczenie w resocjalizacji i innych działaniach pomocowych
}

W wypowiedzi ukierunkowanej na analizę wielowymiarowości relacji międzyludzkich jest miejsce na wskazanie zarówno związków korzystnych rozwojowo (prospołecznych), jak i na obszar kontaktów toksycznych, związanych z negacją norm społecznych. Wprawdzie układ stosunków społecznych $\mathrm{z}$ reguły sprzyja osiąganiu integralności rozwojowej, ale mogą wystąpić sytuacje i okoliczności, które proces ten osłabiają w różnym stopniu i z różnymi skutkami. Takim właśnie - zakłóconym - relacjom społecznym poświęcona jest niniejsza wypowiedź.

\section{Tytułem wprowadzenia - relacje międzyludzkie zakłócone przestępstwem a powstawanie warunków do przebaczania}

Przedmiotem zainteresowania jest obszar problemowy specyficznych relacji społecznych, budowanych zachowaniami ludzkimi naruszającymi wieloaspektową nietykalność innych ludzi. Opisane zostaną między innymi wymiary relacji w oczywisty sposób niszczących - na przykład generowane

* Dr Tomasz Wach jest adiunktem w Katedrze Pedagogiki Opiekuńczej w Instytucie Pedagogiki Katolickiego Uniwersytetu Lubelskiego Jana Pawła II. Adres: Instytut Pedagogiki KUL, ul. Droga Męczenników Majdanka 70, 20-325 Lublin; e-mail: tomasz.wach@interia.pl. 
czynami zabronionymi i przestępstwami. Opis ten zostanie dokonany w kontekście problematyki „krzywdy”, doznawanej przez „pokrzywdzonych”, co pozwoli podjąć próbę zwrócenia uwagi na złożony problem „przebaczania” sprawcom. Takie ukierunkowanie problemowe wymaga wskazania na wielość możliwych do wystąpienia konfiguracji osobowych i ogólniej - warunków egzystencjalnych, stanowiących tło relacji „ofiara-sprawca”.

Złożoność problematyki określonej tytułem wymaga wskazania na szereg dodatkowych kwestii kontekstualnie z nią związanych. Wszystkie one dotyczą różnych wymiarów relacji międzyludzkich powstających lub modyfikowanych zachowaniami aspołecznymi. Jako pierwszy musi zatem zostać poruszony wątek norm społecznych, przyjętych jako kierunkowe (osiowe). Jest oczywiście wychowawczo postulowane, by były to normy prospołeczne, oparte na ,normach moralnych ważnych ogólnie" ${ }^{1}$ i by zawierały wskazania na konieczność przestrzegania wartości podstawowych - w rodzaju dobra wspólnego, nienaruszalności, godności ludzkiej czy ochrony życia. Jednak duży stopień komplikacji okoliczności egzystencjalnych niesie ze sobą negatywne skutki, między innymi dotyczące ryzyka negatywnego ukierunkowania się procesów rozwojowych. Negacje norm głównych i cyrkularnie związane z nimi aspołeczne kierunkowanie się procesu wartościowania może wygenerować postawy szkodliwe, toksyczne, niszczące układy relacyjne $\mathrm{z}$ drugim człowiekiem. Takie sytuacje są udziałem między innymi sprawców naruszeń norm społeczno-prawnych, w tym dokonujących czynów zabronionych i przestępstw. Oczywiście biorą w tym udział także pokrzywdzeni/ofiary - co powoduje, że stopień komplikacji problemu staje się bardzo poważny.

Zagadnienie przebaczania za doznawane krzywdy, omawiane w kontekście oddziaływań resocjalizacyjnych, lokuje się jako ważne w całościowym procesie konceptualizacji procedur pomocowych, przywracających normę społeczną ${ }^{2}$. Nie jest to niestety zagadnienie należycie podkreślane, na przykład w ofercie pomocowej/resocjalizacyjnej kierowanej do sprawców, a wydaje się, że powinno zająć bardziej eksponowane miejsce w działaniach wspierających ofiary ${ }^{3}$. Należy powiedzieć wprost, że obecny, instytucjonalny system norm społeczno-prawnych niedostatecznie służy eksponującej

${ }^{1}$ Andrzej Szostek, Normy i wyjątki (Lublin: KUL, 1980), 34.

2 Marek Konopczyński, „Kierunki zmian teorii i metodyki oddziaływań resocjalizacyjnych w Polsce", w: Wspótczesne kierunki zmian w teorii i praktyce resocjalizacyjnej, red. Marek Konopczyński, Wiesław Ambrozik (Warszawa: CMPPP, 2009), 8.

${ }^{3}$ Maxie C. Maultsby, Racjonalna Terapia Zachowania (Poznań: Alterna, 1992), 167. 
centralizacji omawianych tu zagadnień. Wprawdzie zwraca się uwagę na instrumentalny wymiar relacji interpersonalnych tworzonych na przykład przestępstwem, koncentruje się na działaniach formalnych (prawno-karnych) wobec sprawców, ale jakby słabiej eksponuje się wątek krzywdy doznawanej przez ofiary $\mathrm{w}$ wymiarze głębokim, związanym między innymi z poczuciem wielowątkowego naruszenia godności ludzkiej, skutkującego na przykład pojawieniem się cech PTSD (ang. posttraumatic stress disorder-zespół stresu pourazowego). Stopień skomplikowania tych problemów jest związany głównie z następującymi okolicznościami:

1. Każde ludzkie zachowanie, będące wynikiem świadomie podejmowanych decyzji, czyli realizowane przez ludzi mających wolną wolę ${ }^{4}$, jest relacyjne, czyli dotyczy w pierwszej kolejności drugiego, konkretnego człowieka, ale i jakiegoś kręgu społecznego, czyli szerszych zbiorowisk ludzkich. Innymi słowy, nie ma takich ludzkich zachowań, które w żaden sposób nie skutkują społecznie;

2. Czyny zabronione/przestępstwa ${ }^{5}$ tworzą nowe relacje społeczne lub modyfikują dotychczasowe, przy czym są to relacje toksyczne dla obu stron (sprawcy i ofiary), choć oczywiście za ich kreowanie odpowiada sprawca i to na nim spoczywa odpowiedzialność;

3. Pojęcia „czynów zabronionych” i ,przestępstw” są czytelnie zdefiniowane (między innymi kodeksowo), ale warto pamiętać, że krzywdzenie drugiego człowieka może się realizować w licznych zachowaniach/działaniach, nie tylko definiowanych formalnie/kodeksowo jako zabronione. Jest wręcz tak, że katalog takich (krzywdzących) możliwości jest w świadomości społecznej znacznie liczniejszy niż sformalizowana lista tworzona kodeksem karnym ${ }^{6}$;

${ }^{4}$ Co oznacza zachowanie tzw. poczytalności, rozumianej jako zdolność człowieka do oceny kontekstów własnych zachowań, podejmowania samodzielnych decyzji o ich ukierunkowaniu się, w tym do dokonania analizy skutków, jakie dane zachowania powodują.

${ }^{5}$ Czyn zabroniony jest pojęciem znaczeniowo szerszym niż przestępstwo. W artykule oba terminy są stosowane w pewien sposób zamienne, ale warto zwrócić uwagę, że posługiwanie się skonkretyzowanym przestępstwem jest uprawione tylko w sytuacjach, gdy spełnione zostają warunki kodeksowe (czyn ludzki dokonany w warunkach kontroli, czyli przez sprawcę zdolnego ocenić skutki i przyjąć odpowiedzialność, społecznie szkodliwy, określony jako zabroniony).

${ }^{6}$ Rekomendowane jest tu potraktowanie Kodeksu karnego jako swoistej „listy” ludzkich zachowań zabronionych, czyli w wyniku umowy społecznej uznanych za poważnie szkodliwe. Rekomendacja ta wydaje się szczególnie czytelna dla przedstawicieli nauk społecznych, pragnących dostrzegać szerokie konteksty ludzkich relacji. Kodeks karny traktowany jako „lista 
4. Resocjalizacja jest traktowana wieloaspektowo, głównie przez specjalistów. Potocznie jednak kojarzy się z oddziaływaniami podejmowanymi wobec sprawców - na przykład w wymiarze instytucji wychowawczych w przypadku nieletnich czy zakładów penitencjarnych w przypadku ludzi dorosłych. Jest to oczywiście uzasadnione, ale daleko niewystarczające, ponieważ wydaje się, że nie dość szeroko eksponuje się sytuację ludzi krzywdzonych/ofiar. Rekomendowany jest tu pogląd, że pełna ocena kontekstów przestępstwa musi zawierać analizę sprawcy (podmiotowej strony przestępstwa), czyli jego cech osobowych, ale i stanu, w jakim sprawca pozostawil ofiarę ${ }^{7}$. Kluczowe staje się także ocenienie stopnia gotowości sprawcy do wyrównania wygenerowanych swoją działalnością strat, o czym będzie mowa szerzej w dalszej części tekstu. Tym samym wielokontekstowa resocjalizacja (czyli resocjalizacja rozumiana najszerzej) powinna uwzględniać elementy oddziaływań na relację ofiara-sprawca, ale i dostrzegać konieczność oferowania specjalistycznej pomocy pokrzywdzonym, nawet z wywieraniem pewnego nacisku na sprawców w kierunku przejmowania przez nich odpowiedzialności za wywołane sytuacje. Powinien to być proces systemowy, ukierunkowany wychowawczo;

5. Każde ludzkie zachowanie ma kontekst społeczny, ale szczególnie warto podkreślić, że dotyczy to także zachowań toksycznych. Działaniowa aktywność ludzka jest przejawiana w wyniku pojawienia się swoistych dyspozycji realizacyjnych, wywoływanych w wyniku przyjmowania rekomendacji socjalizacyjnych z otoczenia. Sprawcy naruszeń norm społecznych, w postaci wywierania krzywdzącego wpływu na innych, podejmują swoją aktywność w wyniku uznania, że osiągną jakieś istotne korzyści. Odbywa się to często w kontekście neutralizacji znaczenia własnych zachowań, a w skrajnych sytuacjach może to mieć postać nawet reifikowania ofiar9 . Jeśli zatem oczywiste są społeczne konteksty zachowań toksycznych, to takie

zachowań" umożliwia dostrzeżenie postulowanych przez ustawodawcę kierunków aktywności. Wprost wskazywane jest wprawdzie to, co szkodliwe i podlega np. karze, ale pozwala to wnioskować na temat pożądanej aktywności w relacjach społecznych.

7 Krystyna Kmiecik-Baran, Młodzież i przemoc (Warszawa: PWN, 1999), 47.

${ }^{8}$ Marian Nowak, Podstawy pedagogiki otwartej (Lublin: RW KUL, 2000), 239.

9 Brunon Hołyst, Psychologia kryminalistyczna (Warszawa: Lexis Nexis, 2009), 189. 
też - społeczne - musi być podejście do problemu resocjalizacji. Rekomendowany jest tu zatem pogląd dotyczący celowości systemowego traktowania resocjalizacji, z podkreśleniem cyrkularnej zależności między okolicznościami egzystencjalnymi wywołującymi gotowość do danych zachowań aspołecznych, ale i decydującymi o powodzeniu procesów korekcyjnych, przywracających normę społeczną w funkcjonowaniu sprawców i obliczonych na pozytywną stabilizację stanu pokrzywdzonych.

Jeśli zatem wszystkie ludzkie zachowania mają kontekst społeczny, to muszą wywoływać jakieś zmiany w otoczeniu. W przypadku przestępstw, ale także niepenalizowanych formalnie działań, naruszających osobistą nietykalność innych, jest to nader oczywiste. Relacyjny charakter zachowań toksycznych uzasadnia wprowadzenie do obecnej analizy pojęć krzywdy i przebaczania - a ponieważ treść dalszych analiz dotyczyć będzie właśnie relacyjnego wymiaru szkodliwych relacji budowanych zachowaniami aspołecznymi, w tym przestępnymi, konieczne tym samym staje się wskazanie na kręgi społeczne, których problem dotyczy. Zarówno w samym akcie przestępstwa, jak i w późniejszych kontaktach między ofiarą a sprawcą, biorą udział następujący ludzie i ich otoczenie:

1. ofiary (pokrzywdzeni);

2. najbliższe otoczenie ofiar (pokrzywdzonych, najczęściej chodzi o rodzinę, ale także o ludzi, z którymi utrzymywany jest bezpośredni kontakt i których akt przestępstwa dotknął emocjonalnie);

3. ludzie z dalszych kręgów społecznych związanych z ofiarami (pokrzywdzonymi), chodzi o członków grup szkolnych, zawodowych, które znały ofiary, choć mogły z nimi nie utrzymywać bezpośrednich i stałych kontaktów;

4. ludzie z szerszego otoczenia, którzy nie znali ofiar, ale po otrzymaniu informacji o zdarzeniach sympatyzują z nimi, identyfikują się. Może to być nawet dość liczna grupa ludzi, bowiem współczesne drogi przekazu informacji pozwalają docierać do szerokich grup odbiorców;

5. sprawcy zdarzeń (przestępstw, zachowań traumatyzujących), zachowujący wolną wolę, czyli mogący podejmować decyzje (wieloaspektowo poczytalni w myśl litery prawa) ${ }^{10}$;

${ }^{10}$ Stanisław Kowalczyk, Wolność natura i prawem człowieka (Sandomierz: Wyd. Diecezjalne w Sandomierzu, 2000), 6. 
6. najbliższe otoczenie społeczne sprawców, głównie ich rodziny, ale także osoby pozostające w kontakcie bezpośrednim i związane ze sprawcami emocjonalnie;

7. ludzie z dalszego otoczenia społecznego sprawców (podobnie jak w przypadku ofiar chodzi o członków grup szkolnych, zawodowych, dalszych sąsiadów itd.);

8. szersze otoczenie społeczne, które po otrzymaniu informacji o zdarzeniach w pewien sposób identyfikuje się ze sprawcami lub przynajmniej jest skłonne relatywizować wymiar ich zachowań. Może tu chodzić np. o uznawane wartości i normy z zakresu podkultury dewiacyjnej, opozycyjnej wobec norm głównych (w pewnych środowiskach takie postawy są nadreprezentowane).

Do wymienionego zestawu należy dołączyć wszystkich ludzi, którzy w jakikolwiek sposób mają informacje o danych zdarzeniach, którzy nie identyfikują się ze stronami, ale wyrabiają sobie poglądy na temat ogólnego poziomu bezpieczeństwa w kraju, działania systemu wymiaru sprawiedliwości, funkcjonowania instytucji powołanych do rozwiązywania problemów przemocy ${ }^{11}$, instrumentalizowanej agresji ${ }^{12}$, przestępczości. Oczywiście, im bardziej spektakularne wydarzenie (charakter przestępstwa), tym większy jego rozgłos, ale należy tu wyraźnie powiedzieć, że nawet toksyczne relacje międzyludzkie, które nie są przedmiotem analiz chociażby w mediach (czyli wiedza o nich nie dociera do szerszych kręgów odbiorców), także są niebezpieczne, ponieważ niszczą strukturę relacji międzyludzkich i mogą generować poważne straty emocjonalne u ich uczestników.

\section{Pomoc pokrzywdzonym i resocjalizacja sprawców a system reakcji społecznej}

Relacyjność wszystkich zjawisk społecznych, w tym także (jak przestępstwa) aspołecznych i antyspołecznych, uzasadnia wyrażenie rekomendacji, że próby korekty (wychowawczej, socjalnej, resocjalizacyjnej), muszą się dokonywać w układach zależnościowych, czyli z angażowaniem wszystkich uczestników, nie tylko bezpośrednich stron. Jest przy tym oczywiste, że dany akt społeczny, w tym przypadku akt przestępczy, nie jest jednakowo definiowany przez ofiary i sprawców (czyli także przez kręgi społeczne osób

${ }^{11}$ James Gilligan, Wstyd i przemoc (Poznań: „Media i Rodzina”, 2001), 100.
${ }^{12}$ Arndt Stein, Kiedy dzieci sq agresywne (Warszawa: Jedność, 2002), 24. 
z nimi związanych). Tym samym konieczne jest analizowanie zdarzeń z różnych perspektyw i określanie różnych grup skutków, jakie u stron zdarzenia wywołały. Formułowane wnioski pozwalają określić szanse na realną resocjalizację sprawców, ale i na udzielenie pokrzywdzonym adekwatnej pomocy. Niezmiennie należy pamiętać, że zarówno resocjalizacja sprawców, jak i pomoc oferowana ofiarom powinny być działaniami relacyjnymi i mogą być skuteczne tylko po spełnieniu szeregu konkretnych warunków. W przypadku oddziaływania na sprawców postulowane jest wywołanie u nich refleksji emocjonalnej, dotyczącej negatywnego wymiaru zdarzenia, które wywołali. Powinno to skutkować powstaniem poczucia winy i chęci do wyrównania strat (zadośćuczynienia pokrzywdzonym). Efektem całościowym powinna zatem być zmiana (przeformułowanie) postaw i z jednej strony trwałe zniwelowanie gotowości do dokonywania przestępstw, z drugiej racjonalizacja poziomu empatii, czyli dostrzeżenie, że szkodliwe działania mają charakter niszczący drugiego człowieka ${ }^{13}$. To naturalnie stan zakładany jako korzystny, stale rozpatrywany przy początkowym, wstępnym analizowaniu szans na przyjęcie przez sprawców oferty resocjalizacyjnej. W licznych przypadkach taka oferta jest realnie realizowana w wyniku jej przyjęcia, ale niestety, także liczna jest grupa sprawców opozycyjnych, niewłączających się czynnie w proces ,własnej zmiany”. Wobec takich ludzi system reaguje formalnie, na przykład prewencyjnie ${ }^{14}$. Są oni traktowani zgodnie z zasadami reakcji prawno-karnej, czyli mogą być chociażby izolowani penitencjarnie, ale przez cały okres pobytu mogą pozostawać bierni i wręcz utrwalać swoje aspołeczne (oraz antyspołeczne) wartości i wynikające $\mathrm{z}$ nich postawy.

Konsekwencją uznania poglądu, że przestępstwo (tak jak każde działanie traumatyzujące drugiego człowieka) jest relacyjne, staje się wskazanie na zasadność racjonalizowania jego (przestępstwa) skutków także w układzie międzyosobowym. Oczywiście procedury resocjalizacyjne - wypra-

13 Simon Baron-Cohen, Teoria zła (Sopot: Smak Słowa, 2014), 23.

${ }^{14}$ W kontekście tej uwagi możliwe jest - ostrożne - sformułowanie spostrzeżenia, że wszyscy osadzeni w zakładach karnych, którzy nie przyjmują oferty udziału w programowanym systemie odbywania kary pozbawienia wolności (czyli karę odbywają w systemie zwykłym), należą do grupy do pewnego stopnia opozycyjnej wobec oferty resocjalizacyjnej. Zgoda na udział w, wymagającym pewnej przynajmniej aktywności własnej, programowanym systemie odbywania kpw stanowi swoisty dowód, że osadzeni realnie przepracowują swoje postawy, w tym są skłonni do refleksji na temat skutków swoich czynów. Uwaga ta jest formułowana jako do pewnego stopnia kontrowersyjna, ale zdaniem autora powinna stanowić istotny element szerszej dyskusji systemowej. 
cowywane $\mathrm{w}$ toku wieloletnich doświadczeń, formułowane teoretycznie i wiele razy weryfikowane w praktyce - odnoszą się także do relacji międzyludzkich. Charakterystycznym dowodem jest proceduralne/formalne przyjęcie schematów procedur mediacyjnych, co w zamyśle ma służyć lepszemu zrozumieniu skutków swoich działań przez sprawców, ale także umożliwiać pokrzywdzonym odzyskanie stanu równowagi ${ }^{15}$. Mimo że mediacje między ofiarami a sprawcami nie są w stanie zastąpić całkowicie procedur sądowych (rozpraw), mogą wydatnie wspomóc procesy stabilizujące egzystencję (obu stron, ale szczególnie pokrzywdzonych). Warto pamiętać, że mediowane mogą być tylko sytuacje, gdy panuje jednoznaczność na temat sprawstwa, winy, ale i chęci zadośćuczynienia ze strony sprawców. Jednak w praktyce okazuje się, że dobrze metodycznie przeprowadzone sesje mediacyjne są bardzo pomocne $\mathrm{w}$ racjonalizowaniu konfliktów wywołanych zachowaniami aspołecznymi.

System wymiaru sprawiedliwości kształci specjalistów z zakresu mediacji sądowych i działania te zasługują na jednoznaczną akceptację. Mediacje pozwalają rozluźnić sztywny „gorset” procedur sądowych, choć liczna jest grupa spraw, które mogą być rozstrzygane wyłącznie w drodze rozpraw (sądowych). Procedury, metody i techniki mediacyjne doskonale służą rozwiązywaniu charakterystycznej grupy konfliktów międzyludzkich, zresztą nie tylko stricte sądowych. Przecież to przy wykorzystaniu „technologii” mediacyjnych możliwe jest wykazanie sprawcom, że krzywdzeni przez nich ludzie autentycznie przeżywają swoje krzywdy. Procedury działają w obie strony, bowiem bywa często, że pokrzywdzeni czynami zabronionymi dostrzegają okazję do wykazania sprawcom swojej dezaprobaty, choć także zdarza się, że dochodzi do przebaczenia im (najczęściej po usłyszeniu przeprosin...). Widoczna gotowość pokrzywdzonych do wejścia w kontakt ze sprawcami może wywołać u tych ostatnich zachowania nawet ekspiacyjne i wtedy łatwiej dochodzi do wyrażenia woli naprawienia szkód i przeproszenia. Oczywiście, opis powyższy jest uogólniony, dotyczy pewnej liczby mediowanych spraw, czyli może nie być reprezentatywny dla wszystkich mediacji realizowanych $\mathrm{w}$ ramach procedur sądowych. Jednak zwrócenie uwagi, że mediacje sądowe tworzą warunki do bezpośredniego kontaktowania się sprawców i ofiar oraz - co niezwykle ważne - są to warunki bezpieczne dla pokrzywdzonych, otwiera przestrzeń analityczną, dotyczącą warunków i okoliczności odpowiednich do wyrażenia przez sprawców woli

${ }_{15}$ Autor ukończył specjalistyczne szkolenie dla mediatorów sądowych organizowane przez Senat RP, jest uprawnionym mediatorem sądowym wpisanym na listę SO w Lublinie. 
przeproszenia swoich ofiar, a także do uznania przez pokrzywdzonych, że są gotowi wybaczyć swoim krzywdzicielom.

Dalsze omawianie uwarunkowań relacji ofiar ze sprawcami zostanie dokonane $\mathrm{z}$ uwzględnieniem poszerzonego kontekstu relacji międzyludzkich, z osiowym potraktowaniem kwestii przebaczania i przebaczenia, czyli pojawią się odniesienia do: „krzywdy”, „winy”, „kary”, „zadośćuczynienia”, „odpłaty” oraz, naturalnie, do „sprawiedliwości”. Wypowiadane treści skupią się zatem w dużej części na aspektach emocjonalnych, związanych z przyjęciem określonych schematów normatywnych i systemów wartości. Tym samym aspekty stricte prawne nie zajmą miejsca dominującego, ale też nie zostaną całkowicie pominięte, szczególnie przy wskazywaniu na związki występujące między postrzeganiem formalnych reakcji prawno-karnych z poglądami na temat sprawiedliwości.

\section{Okoliczności i czynniki wpływające na wypracowywanie decyzji o przebaczeniu}

Podstawowa wątpliwość, która pojawia się w tym momencie, może zostać pokazana operacjonalizującym pytaniem: czemu służy przebaczenie? Niewątpliwie zasadne będzie początkowe spojrzenie na problem poprzez wskazanie na stan przebaczenia i na proces przebaczania. Mogą się one łączyć - wtedy przebaczanie kończy się przebaczeniem. Jednak przebaczanie (proces) nie musi się skończyć przebaczeniem (jego aktem). Wydaje się też, że nie ma tu żadnych reguł czasowych i nie można określić, ile czasu musi upłynąć, by można było komuś przebaczyć, nawet mimo wstępnej gotowości przekładającej się na inicjację procesu przebaczania. Można wskazać, że przebaczanie i przebaczenie dotyczą różnych okoliczności i związków międzyludzkich, jednak w obecnej wypowiedzi skoncentrowano się na relacjach budowanych przestępstwem, czyli wprost chodzi o przebaczenie dotyczące ofiar i sprawców.

W kontekście dotychczasowych uwag możliwe jest zdefiniowanie okoliczności sytuacyjnych związanych z kwestią przebaczania/przebaczenia.

I tak przebaczanie/przebaczenie:

1. ma różne wymiary i łączy się z wyrządzoną (sprawca) i doznaną (ofiara) krzywdą;

2. dotyczy poziomów percepcji, dostępnych obu stronom (ofiarom i sprawcom), przyjętych perspektyw patrzenia na zjawisko krzyw- 
dzenia drugiego człowieka, czyli ma związek między innymi z sumieniem;

3. jest procesem (przebaczanie) i aktem (przebaczenie) i oba te wymiary znacznie wykraczają poza spersonalizowany, dwustronny wymiar relacyjny „ofiara-sprawca”, czyli dotyczą szerszego wymiaru społecznego (opis w dalszej części tekstu);

4. może być rozpatrywane $z$ wielu perspektyw: formalnej, osobistej, także religijnej, przy czym perspektywy te łączą się, dając efekt w postaci skutku, czyli aktu przebaczenia lub jego braku;

5. dokonywane/wyrażane przez ofiary może, ale nie musi, zależeć od postaw krzywdzicieli (sprawców przestępstw). Może być wyrazem uznania, że sprawca jako Osoba Ludzka nie może być „zły”, choć przejawia złe zachowania.

Kończący proces (przebaczania) akt (przebaczenia) jest uwarunkowany licznymi okolicznościami dotyczącymi doświadczeń obu stron (ofiary, sprawcy).

„Przebaczanie”, analizowane w kontekście oddziaływań resocjalizacyjnych, wymaga swoistego dookreślenia poprzez wskazanie, że może ono istotnie wesprzeć proces korekty wychowawczej, choć nie jest koniecznym warunkiem. Oczywiście, wypracowanie w sobie gotowości do przebaczenia komuś, na przykład dokonywane u ofiary w stosunku do sprawcy, wymaga wcześniejszego przygotowania normotwórczego i postawotwórczego. Jeśli resocjalizacja zostanie potraktowana systemowo, czyli pojęciem tym objęte zostaną szerokie działania adresowane do sprawców i ich środowisk, ale z pełnym dostrzeganiem także sytuacji ofiar i ich bliskiego otoczenia społecznego, to niewątpliwie takie spersonalizowanie relacji, jakie zachodzi przy przebaczaniu, jest korzystne. Stanowi z jednej strony dowód wysokich kompetencji społecznych ofiary, ale i może nakłaniać sprawcę do rzeczywistej zmiany swoich poglądów dotyczących uznawanych norm moralnych, przekładanych na postawy i zachowania. Tym samym może prowadzić do trwałej rezygnacji z przemocy i przyjęcia prospołecznej linii postępowania ${ }^{16}$. Pokrzywdzony przebaczający swojemu sprawcy z pewnością odczuwa wieloaspektową satysfakcję, stanowczo pomaga ona w zniwelowaniu traumy. Wymiar pozytywnych skutków, odczuwanych przez przebaczające ofiary, może być zarówno indywidualny (w pełni osobisty), jak i społeczny - to $\mathrm{w}$ przypadku, gdy podzielą się one swoimi opiniami z otoczeniem. Prze-

${ }^{16}$ Kevin Browne, Martin Herbert, Zapobieganie przemocy w rodzinie (Warszawa: PARPA, 1999), 27. 
baczenie może stanowić koniec charakterystycznego okresu żałoby, jakim jest rozpamiętywanie zdarzeń i przejmowanie odpowiedzialności za nie (to poważne obciążenie w egzystencji na przykład ofiar przemocy gwałtownej i stanowi znaczące wyzwanie dla terapeutów, pomagających niwelować skutki doznanych urazów).

Rozpatrywanie, czym jest przebaczenie i jakie jest jego miejsce w odbudowywaniu pozytywnych relacji międzyludzkich zniszczonych przestępstwem, wymaga zwrócenia uwagi na wielowymiarowość zagadnienia. Z przebaczeniem człowiek styka się regularnie i dokonuje się to $\mathrm{w}$ obszarach ${ }^{17}$ :

1. Religijnym, biblijnym: przebaczenie jest odpowiedzią Boga na grzech. Szczery żal za grzechy, jaki człowiek wyraża, powinien wypływać z głębi, nie może być powierzchowny, wyłącznie deklaratywny, czyli nieprzełożony na zmianę stosunku emocjonalnego do swoich zachowań. Daje to podstawę do otrzymania przebaczenia. W omawianym obszarze przebaczenie jest przejawem Boskiego miłosierdzia dla grzeszników. Czytelnym przykładem, wyznaczającym osobom wierzącym linię postępowania, jest akt przebaczenia wyrażony przez Jezusa Chrystusa wobec swoich oprawców;

2. Duchowym: jest rozumiane zamiennie z odpuszczeniem grzechów, czyli z rolą samego Boga. Jednocześnie przebaczenie jako łaska Boga wymaga nawrócenia człowieka. Wskazuje się też, że przebaczenie ma być aktem woli;

3. Psychologicznym, indywidualnym: przebaczenie oznacza zmianę postaw wobec krzywdzicieli. Występuje przekonanie, ze przebaczenie towarzyszy pojednaniu (obu stron) i jako takie może być znaczącym elementem procesów terapeutycznych, obliczonych zarówno na wspieranie ofiar, jak i na zmiany postaw sprawców.

Wymienione obszary mają wspólne zakresy znaczeniowe i rozpatrywanie przebaczania powinno się dokonywać z uwzględnieniem pełnej perspektywy analitycznej wyznaczanej powyższymi wskazaniami. Dla systemowej resocjalizacji, ale także dla związanych z nią innych działań pomocowych (szczególnie dla pracy socjalnej świadczonej na rzecz rodzin ofiar) istotne znaczenie ma dostrzeganie następujących wymiarów relacji społecznych skontekstowanych z przestępstwem, gdzie przebaczenie może zaistnieć:

1. ofiara (przebacza) - sprawcy;

2. rodzina ofiary - sprawcy;

17 Na podstawie: Andrzej Jasiński, Wojciech Zyzak, Aldona Król, „Przebaczenie”, w: Encyklopedia Katolicka, t. XVI (Lublin: TN KUL, 2012), 604. 
3. ofiara - rodzinie sprawcy;

4. rodzina ofiary - rodzinie sprawcy;

5. rodzina sprawcy - samemu sprawcy;

6. społeczeństwo - sprawcy;

7. społeczeństwo - rodzinie sprawcy.

Takie dość szczegółowe wskazanie obszarowe wynika ze złożoności modyfikacji relacji międzyludzkich, które są dokonywane przestępstwami (szczególnie o charakterze gwałtownym, bezpośrednio krzywdzącymi ofiary). Wymiary relacji mogą występować tak jak je wyżej wskazano, ale też mogą się łączyć, tworząc nowe konfiguracje - bywa, że bardzo złożone, tworzące nowe, szerokie i poważnie skutkujące problemy. Czytelnym przykładem jest „gotowość do przestępstwa”. Należy ją traktować jako złożoną kategorię problemową, nabywaną $\mathrm{w}$ toku licznych interakcji sprawcy $\mathrm{z}$ otoczeniem i przy nałożeniu się cech indywidualnych. Uzasadnione zatem jest uznanie, że świadomi swoich czynów sprawcy (o takich jest tu mowa) muszą przynajmniej częściowo rozpatrywać skutki swoich działań ponoszone przez ofiary. Mimo to przejawiają zachowania szkodliwe, często poważnie traumatyzując innych...

O ile spersonalizowane wymiary relacyjne (wymienione wyżej pkt. 1-5) nie budzą wątpliwości, to już poszerzony obszar społeczny zasługuje na podkreślenie i wymaga dodatkowego komentarza (pkt. 6 i 7). W sformułowaniu, że „społeczeństwo" może przebaczyć sprawcy i jego rodzinie, chodzi o podkreślenie wychowawczego (i pozytywnie socjalizującego) znaczenia wspólnot. Takimi są oczywiście także rodziny, ale akurat w tych dwóch punktach jest mowa o wymiarze nieco szerszym. Poglądy rekomendowane przez ważne dla danego człowieka wspólnoty pozarodzinne muszą być brane pod uwagę zarówno przy kryminologicznej ocenie etiologicznej zachowań aspołecznych, jak i przy projektowaniu oddziaływań normalizujących stosunki społeczne, w tym wpływających na sprawców. Tym samym uznanie przez jakąś ważną w przestrzeni społecznej wspólnotę, że dokonuje ona przebaczenia sprawcy (krzywdzącemu jednego z jej członków), ma istotne znaczenie całościowe. Może się wpisywać w proces wzmacniania szerokich więzi społecznych, bowiem z pewnością podtrzymuje poczucie wspólnotowości życia.

Analiza wymiarów relacyjnych, w których może się przejawić przebaczenie za doznane krzywdy, musi być dokonywana z docenieniem znaczenia „winy”. To poważny problem i wymaga specjalnego skomentowania. Oto „wina” może być definiowana jako osobista zarzucalność - a dzieje się tak w przypadku decyzji sądowych (wyroków), gdzie uznaje się „winę” spraw- 
ców przestępstw. Może to być wina umyślna, tak mogą być popełniane wszystkie przestępstwa, zatem zbrodnie i występki. Może też zostać uznana wina nieumyślna - w takim razie może chodzić tylko o występki (zbrodnie mogą być popełnione tylko umyślnie). Charakterystyczne jest, że problem winy może być rozpatrywany niejako z zewnątrz - na przykład w toku zaznaczonych wyżej procedur sadowych, ale też od wewnątrz - czyli z perspektywy osoby, która nabywa poczucia winy (czuje się winna w wyniku dokonania ocen wewnętrznych, mających związek z procesami zachodzącymi w obszarze sumienia). Oba te wymiary mogą się łączyć, ale może się też zdarzyć, że jeden z nich się nie pojawi - będzie tak na przykład w przypadku sprawcy uznawanego sądownie za winnego dokonania przestępstwa, ale zupełnie nieodczuwającego własnej winy, niedostrzegającego w swoim zachowaniu żadnych elementów szkodzących ofiarom.

Wina, przypisywana w toku postępowań sądowych, ale i wewnętrznie odczuwana przez sprawców, łączy się z kwestią „kary”. Ta powinna być indywidualna i adekwatna do winy oraz do stopnia (skali) wyrządzonej szkody. Nakładają się tu zatem specyficzne, ważne kategorie problemowe. Wina przypisywana sądownie sprawcom przestępstw wynika $\mathrm{z}$ oceny stopnia rozumienia przez nich znaczenia/skutków własnych zachowań i ma to związek $\mathrm{z}$ oceną poziomu rozwoju. Pewne kategorie ludzi nie mogą być obarczone winą, bo definicyjnie uznano, że nie rozumieją dostatecznie dobrze tego, co robią (mowa głównie o małoletnich, którym przypisano kodeksową cechę „bezwzględnej nieodpowiedzialności”). Innych ludzi, których formalnie można uznać za dojrzałych na tyle, że mają zdolność zrozumienia kontekstów swojej aktywności, także można poddawać ocenom specjalistycznym (np. psychiatrycznym) w celu potwierdzenia, czy poczytalność, czyli świadomą decyzyjność, zachowują. Tak się dzieje szczególnie w przypadku sprawców czynów o ciężkim charakterze gatunkowym - czyli wtedy, gdy ofiary doznają poważnych uszkodzeń (fizycznych, psychicznych). Domniemywa się wszak, że człowiek normalnie socjalizowany nie jest zdolny do popełniania zbrodni. Jednak przypadki ich dokonania występują i obciążając system społeczny wymagają reakcji. Analizy dotyczące stopnia rozwoju sprawców, stanu ich dojrzałości społecznej, są stale dokonywane przez specjalistów inicjujących proces resocjalizacji. Działania takie są obliczone na wskazanie optymalnych posunięć, ukierunkowanych na wywołanie pozytywnych i trwałych zmian w zakresie wartościowania. Stałymi elementami takich diagnoz jest odnoszenie się do kwestii:

a) odczuwanej przez sprawców winy;

b) gotowości do zadośćuczynienia ofiarom; 
c) gotowości do naprawienia szkód;

d) stopnia gotowości do przyjęcia kary;

e) poziomu refleksyjności własnej, dotyczącej oceny skutków czynów, ale i wnioskowania na przyszłość.

W wymiarze instytucjonalnym kara może być wprawdzie zmniejszona lub może być orzeczona jej mniej dotkliwa postać, ale zupełnej rezygnacji $\mathrm{z}$ karania $\mathrm{w}$ pewnych przypadkach nie można oczekiwać. Jest to związane ze „sprawiedliwością”, w tym pozytywnie rozumianą „sprawiedliwością społeczną". Nawet za czyny dokonane nieumyślnie (wina nieumyślna) kary są orzekane, choć - jak wspomniano - z reguły mniej dolegliwe (niższe, w zawieszeniu itd.). W wymiarze pozainstytucjonalnym, czyli międzyosobowym (w relacji bezpośredniej „ofiara-sprawca”), rozpatrywanie problemu karania może nie wystąpić. Ofiara może nie chcieć dla sprawcy kary, jeśli ten na przykład wykaże wolę przeproszenia, zadośćuczynienia. Może się też zdarzyć, że ofiara zupełnie nie chce żadnej kary dla sprawcy (nawet niskiej, zawieszonej), ponieważ uznaje, że przebaczenie, jakiego wobec sprawcy dokonuje, jest wystarczające, a kwestią karania nie chce się zajmować. Takie akty, polegające na przebaczaniu sprawcom bez oczekiwania jakichkolwiek aktywności z ich strony, są udziałem ludzi religijnych, przeżywających swoją duchowość i uznających, że sprawcy powinni odpowiedzieć w swoim sumieniu. Oczywiście pokrzywdzeni przestępstwami mają pełne prawo oczekiwać od sprawców wyrównania strat i poddania się karze, jednak należy podkreślić znaczenie przebaczania niejako jednostronnego, gdy ofiara dokonuje takiego aktu (przebaczenia) wypracowując w sobie gotowość do niego, z jednoczesnym brakiem starań ze strony sprawcy. Postawy takie wymagają bardzo wysokiego poziomu dojrzałości osobistej. Znaczenie takich zachowań jest wprost nieocenione, niezwykle wartościowe, stanowi dowód na autentyczną rezygnację $\mathrm{z}$ dalszego obciążania sprawców winą (co powinno wzbudzać refleksje w sumieniach i powodować zmianę postaw).

Rozpatrywanie związku winy i przebaczenia musi się dokonywać także w kontekście wyrażanego żalu (za dokonanie przestępstwa) i okazywanej przez sprawców skruchy. Jednak poważny problem otwarty generuje sytuacja, gdy sprawcy nie chcą uznać swojej winy i nie okazują skruchy, czyli nie widzą też zasadności zadośćuczynienia pokrzywdzonym. W rzeczywistości społecznej takie sytuacje nie są bynajmniej rzadkie, a nawet można wskazać, że w pewnych grupach sprawców są permanentne... Mowa między innymi o sprawcach obciążonych problemem demoralizacji, neutralizujących znaczenie swoich zachowań, a nawet niwelujących wartość samych ofiar. Reifikowanie ofiar jest znane w kryminologii i stanowi wyzwanie dla pedagogów 
chcących opracować oferty resocjalizacyjne. Postawy zaprzeczające traumatyzowaniu ofiar są diagnozowane u sprawców tkwiących w podkulturze dewiacyjnej ${ }^{18}$. Tam o uznaniu własnej winy, czyli także o chęci zadośćuczynienia, najczęściej nie ma mowy. Jest za to przerzucanie odpowiedzialności na ofiary (wskazywanie ich rzekomych prowokacji) i zaprzeczanie znaczenia samych czynów (uznawanie, że nie dokonano żadnego przestępstwa tylko aktu „sprawiedliwej zemsty”, słusznej obrony itd.). Takie postawy sprawców niewątpliwie utrudniają wypracowanie przez ofiary postaw otwartych na przebaczenie, jednak - jak wspomniano - ich całkowicie nie niwelują. W sytuacjach, gdy sprawca nie wyraża zamiaru przeproszenia ofiary, wyrównania strat, czyli zadośćuczynienia, ofiara może mu naturalnie przebaczyć, ale sądowy system reakcji społecznej raczej wymierzy surowszą karę (bo weźmie pod uwagę, że sprawca nie okazał skruchy i nie podjął próby naprawy wyrządzonych szkód, a także nie przeprosił pokrzywdzonych). Wyrażony przez pokrzywdzonego akt przebaczenia sprawcy nie oznacza bowiem rezygnacji z określenia rodzaju odpłaty, jaką ten sprawca musi przyjąć w wyniku oceny jego zachowania przez system instytucjonalny (wymiaru sprawiedliwości). Może to być czytelnie zobrazowane przykładem aktu przebaczenia, jaki Karol Wojtyła wyraził wobec człowieka dokonującego zamachu na jego życie (sprawca odbywał długoletni wyrok pozbawienia wolności, a spotkanie odbyło się w więzieniu). Sytuacja taka będzie łatwiejsza do zrozumienia, gdy wskaże się na fakt, że nie wszyscy ludzie mają gotowość do przebaczenia swoim krzywdzicielom. Powody braku takiej gotowości mogą być różne i może się zdarzyć, że ludzie nie rozumieją istoty przebaczania, jego znaczenia, tła. Może to być dla nich zbyt trudne i mają prawo do takich poglądów. W takich przypadkach działanie systemu wymiaru sprawiedliwości staje się zasadne, bo wpływa na sprawców - pokazując ogółowi (czyli także ludziom sceptycznym wobec przebaczania), że sprawcy ci nie są pozostawieni bez konieczności poniesienia odpowiedzialności. Ponieważ orzekane i stosowane kary mają znaczenie „ekwiwalentów” wobec wyrządzonych $\mathrm{krzywd}^{19}$, stanowią wyraz retrybucji (odpłaty społecznej), to powinny mieć

${ }^{18}$ Więcej uwag na ten temat zawarto w opracowaniu: Tomasz Janusz Wach. Resocjalizacja nieletnich sprawców gwattownych czynów zabronionych (Lublin: KUL, 2009),105.

${ }^{19}$ Ekwiwalentność kar jest doskonale widoczna na przykładzie kodeksowej kary zasadniczej, jaką jest pozbawienie wolności. Uznano, że czas trwania takiej kary oraz warunki, w jakiej jest odbywana, stają się właśnie ekwiwalentem w zamyśle wyrównującym krzywdy, jakie sprawcy wyrządzili ofiarom. Oczywiście karom pozbawienia wolności mogą towarzyszyć różne obowiązki nakładane na sprawców w celu jak najpełniejszego wyrównania strat społecznych. 
znaczenie prewencyjne w wymiarach zarówno indywidualnym (na danego sprawcę bezpośrednio), jak i generalnym (na innych potencjalnych sprawców). Kary wymierzane sprawcom przestępstw przez system powinny także podtrzymywać społeczne poczucie sprawiedliwości, utwierdzać obywateli w przekonaniu, że są chronieni.

\section{Przebaczenie a budowanie prospołecznych relacji międzyludzkich}

Podkreślenie znaczenia aktów przebaczenia, dokonywanych przez ofiary na rzecz swoich krzywdzicieli, stanie się pełniejsze przy dostrzeżeniu szerszego zestawu okoliczności kluczowych dla budowania prospołecznych relacji międzyludzkich. Relacje takie są możliwe do zbudowania także w układzie „ofiara-sprawca”, choć (jak wykazano wcześniej) zdarza się, że z różnych powodów nie mogą się wytworzyć. Warto zatem podjąć próbę wskazania tych okoliczności egzystencjalnych, dotyczących ofiar i sprawców przestępstw, które mogą mieć znaczenie konstruktywne społecznie, wspierające proces budowania pozytywnych relacji międzyludzkich, czyli znacząco optymalizujących procesy: resocjalizacji sprawców, ale i stabilizowania sytuacji ofiar.

W świetle dotychczasowych uwag uzasadnione jest zaproponowanie następującego zestawu takich okoliczności:

1. miejsce/pozycja „Osoby Ludzkiej” w uznawanym systemie wartości - ofiar, ale i sprawców: chodzi przede wszystkim o uznawanie takich wartości głównych, jak godność ludzka i dobro wspólne;

2. wymiar doświadczanego przez pokrzywdzonych urazu (stopień traumatyzacji): oczywiście może się wstępnie wydawać, że im większy stopień krzywdy doznanej przez ofiarę, tym trudniej o racjonalizację jej relacji ze sprawcą. Jednak nie jest to zależność aż tak prosta, bo dochodzi tu do głosu także wewnętrzne przekonanie ofiary, że krzywdy należy przebaczać, ale też znaczenie ma postawa sprawcy - na przykład związana z wystąpieniem żalu, chęci naprawy szkód, zadośćuczynienia ofiarom itd.;

3. motywacje sprawców i ich postawy po zdarzeniu: jeśli będą skorelowane z redukcją znaczenia ofiary jako człowieka, czyli nastąpi depersonalizacja ofiar, a siła oddziaływań traumatyzujących, wykazywanych wobec pokrzywdzonych, będzie duża - wtedy trudno będzie liczyć na reaktywowanie pozytywnych relacji (choć nawet 
w takich sytuacjach możliwe są jednostronnie wyrażane przez ofiary akty przebaczenia);

4. potencjał socjalizacyjny $\mathrm{w}$ tych częściach środowiska okolicznego sprawców, które wywierają dominujący wpływ postawotwórczy: przy nadwyżce płynących z otoczenia rekomendacji patologizujących układ relacji ze społeczeństwem wywołanie u sprawców refleksji krytycznych wobec swoich zachowań będzie utrudnione lub wcale nie wystąpi;

5. rekomendacje wychowawcze otrzymywane przez pokrzywdzonych ze swoich środowisk, które mają główne znaczenie postawotwórcze: jeśli procesy socjalizacji i wychowania zostały wzbogacone o elementy dotyczące godnego traktowania innych ludzi, w tym swoich ewentualnych krzywdzicieli, znacznie łatwiej o przebaczenie sprawcom.

Wskazane okoliczności wymieniono jako podstawowe, ale zestaw ten nie jest oczywiście wyczerpujący. Charakter powiązań między nimi jest kołowy (cyrkularny). Powstaje tym samym układ zależnościowy, wynikowo inaczej działający na każdego człowieka, bo dochodzą tu jeszcze inne, niewymienione okoliczności indywidualne (przez to trudne do każdorazowego wskazania, jednak konieczne do uwzględnienia w toku odpowiednio skonkretyzowanych analiz). Powstaje sytuacja, gdy między ofiarami i sprawcami trwa swoista zależność, nawet jeśli nie mają ze sobą bezpośredniego kontaktu. Sprawcy mogą być obejmowani jakimiś działaniami w zamyśle normalizującymi - w podstawowym wymiarze czysto prewencyjnymi, w sprzyjających warunkach może im być składana oferta resocjalizacyjna (zatem może im być proponowany udział w aktywności interakcyjnej, wymagającej zbudowania własnej, pozytywnie ukierunkowanej gotowości do dokonywania w sobie oczekiwanych zmian). Ofiarom także może być oferowana jakaś pomoc - jest to możliwe na różnych poziomach i w odniesieniu do różnych sfer egzystencji (od formalno-prawnej w rodzaju uzyskania statusu oskarżyciela posiłkowego w toczonym procesie karnym, przez ofertę przyjęcia działania socjalnego, aż do pomocy terapeutycznej/psychoterapeutycznej). Poziom ofert pomocowych (dla obu stron) powinien być możliwie najwyższy, z pewnością ich zakres musi uwzględniać liczne cechy i okoliczności osobiste i społeczne dotyczące zarówno samych pokrzywdzonych, jak i sprawców. Nawet jeśli nie ma między nimi kontaktu (na przykład sprawca przebywa w izolacji, a ofiara nie życzy sobie mediacji), należy uwzględniać cechy sytuacji wzajemnych. Informacja, co się dzieje ze sprawcą, może być ofierze przydatna, może wspomóc proces jej terapii, choć nie należy o tym 
mówić wbrew jej woli, należy uszanować życzenie całkowitego braku kontaktu ze sprawcą, nawet na poziomie informacji przekazywanych za pośrednictwem innych osób. Jednak już w oddziaływaniach wobec sprawców za konieczne należy uznać przekazywanie im informacji o stopniu urazu, jakiego doznały ich ofiary. Należy to robić nawet kosztem swoiście odczuwanego dyskomfortu - sprawcy muszą otrzymywać jasny przekaz, dotyczący poziomu krzywdy jaką wyrządzili, czyli wieloaspektowych kosztów ponoszonych przez pokrzywdzonych. To trudny obszar zarówno koncepcyjnie, jak i realizacyjnie. Warto mu się bliżej przyjrzeć właśnie w kontekście problematyki głównej obecnej wypowiedzi, bo kwestia przebaczania, ale także stosunek do winy i zadośćuczynienia, kierunkują działania normalizujące, przywracające stan przestrzegania norm społecznych.

Przyjęcie przez sprawcę informacji o skali dokonanych przez siebie strat zdecydowanie wplywa na większe zrozumienie, czym jest akt przebaczenia ze strony pokrzywdzonych. Sprawca ocenia spowodowane straty i ma szansę pełniej docenić gest ofiary. Powinno to powodować przepracowanie swoich postaw, wyrażenie krytycznej opinii na temat swoich poprzednich zachowań i trwałe przekierowanie aktywności życiowej w kierunku realizowania norm zgodnych z oczekiwaniami społecznymi - w tym przypadku między innymi odrzucających przemoc. Nie zawsze jednak taki proces korekcyjny staje się udziałem sprawców, nawet tych, którym pokrzywdzeni przebaczyli. Oto często brakuje warunku, jakim jest uznanie, że ofiara jest człowiekiem w pełnym znaczeniu; odczuwającym emocje, przeżywającym wydarzenia rozgrywające się wokół, mającym wizje swojego rozwoju. Wskazany wyżej problem z negacją człowieczeństwa (wymieniona już reifikacja) może dotyczyć tych sprawców, którzy nie uczestniczyli w prospołecznych procesach normotwórczych, czyli ich rozwój nie został ukierunkowany pozytywnie. Ze strony takich ludzi mogą paść wyrazy lekceważenia gestu przebaczenia wyrażanego przez pokrzywdzonych. Wszak pełne uświadomienie sobie, czym jest przebaczenie wymaga wyraźnego poziomu kompetencji społecznych, w tym zdolności do empatii, przyznawania się do błędów i przynajmniej minimalnego uznania znaczenia wartości wspólnych, głównie dobra wspólnego i godności człowieka. W strukturze społecznej mogą egzystować ludzie niemający takich kompetencji, ale jednocześnie dokonujący przestępstw. Z ich strony zostanie odrzucony wątek rozpatrywania swojej winy i w konsekwencji nie dojdzie do analizowania zasadności przeproszenia ofiar, zadośćuczynienia im czy innego naprawienia wyrządzanych szkód. Sytuacja taka oznacza, że przebaczenie wyrażone przez ofiary nic dla nich nie znaczy. To dość skrajne stwierdzenie, ale znajduje (niestety) swoje 
uzasadnienie w praktyce kryminologicznej (w diagnostyce sądowej). Jak już wspomniano, wyraźnie obciążający jest w takich przypadkach udział w podkulturze dewiacyjnej, generujący gotowość do postaw i zachowań opozycyjno-buntowniczych, z jednoczesnym neutralizowaniem znaczenia własnej działalności aspołecznej.

Inaczej jest w przypadku, gdy u sprawcy występuje minimalny choćby poziom gotowości do zreflektowania się, uznania, że niektóre własne zachowania mogą być szkodliwe dla innych. Sprawcy tacy stają się gotowi do pełniejszego docenienia ewentualnych aktów przebaczenia. Praktyka resocjalizacyjna (także penitencjarna) zna dość liczne przypadki sprawców nawet zabójstw - zatem czynów, gdzie nie można już mieć bezpośredniego kontaktu z ofiarami, choć z ich rodzinami już tak - którzy proszą o możliwość „zrekompensowania" wyrządzonych krzywd, na przykład pracując nieodpłatnie w hospicjach, domach opieki, nawet w schroniskach dla zwierzą ${ }^{20}$. Postawy takie stanowią dowód na krytyczną wobec siebie refleksję, choć oczywiście nie mogą już przywrócić stanu sprzed przestępstwa. Przy tej okazji warto przypomnieć, że to właśnie zdarzenia zbrodnicze, zatem szczególnie traumatyzujące ofiary (także kończące się ich śmiercią), są z oczywistych względów najtrudniejsze i tym większe znaczenie mają akty przebaczania wyrażane przez pokrzywdzonych i/lub ich najbliższych. Tu także praktyka resocjalizacyjna dostarcza szeregu przykładów.

\section{Postawy otwarte na przebaczanie - próba podsumowania}

Konkludujące odniesienie się do treści tytułowych obecnej wypowiedzi może być zrealizowane poprzez wyrażenie uwagi, że dostrzeganie znaczenia tych postaw ludzkich, które wiążą się z gotowością do przebaczania za doznane krzywdy, wymaga docenienia kontekstów relacji międzyludzkich. W specyficznych sytuacjach społecznych, które są generowane zachowaniami przestępnymi, oznaczane są role społeczne - ofiary, sprawcy, świadków, innych ludzi przeżywających (na przykład członków rodzin). Istotna jest skala wyrządzanej krzywdy, ale i siła subiektywnie odczuwanego urazu (nie jest to bynajmniej oczywiste, bo może wystąpić sytuacja, gdy nawet poważny, z perspektywy obiektywnej, uraz nie jest tak samo traktowany przez

20 Zdzisław Majchrzyk, Nieletni, młodociani, dorośli sprawcy zabójstw (Warszawa: IPiN, 2004), 37. 
człowieka go doznającego; może też wystąpić sytuacja odwrotna). Każda sytuacja ma swoją specyfikę, tym bardziej należy doceniać gotowość pokrzywdzonych do dokonywania aktów przebaczania swoim krzywdzicielom. Postawy takie powinny być odpowiednio promowane. Samych sprawców warto nakłaniać do przyjmowania uwag o wymiarze swoich czynów, a ci, którzy wyrażą autentyczną wolę wyrównania wyrządzonych strat, powinni otrzymywać szanse szybszego powrotu do społeczeństwa. We własnych sumieniach dokonają oni koniecznych ocen wartościujących.

Zamieszczone wyżej treści zostały przez autora sformułowane z zamiarem zaproszenia do dyskusji. Efektywność wspierającej korekty społecznej, w tym oddziaływań resocjalizacyjnych i innych rodzajów aktywności pomocowej (chociażby pracy socjalnej rozumianej tradycyjnie) jawi się jako istotny problem i zadanie społeczne między innymi dla pedagogów. Dyskusje - zarówno eksperckie, jak i realizowane potocznie - powinny się odbywać także w pozwalającej na szerszy zasięg przestrzeni medialnej, ponieważ zdecydowanie służą lepszemu zrozumieniu trudnych zagadnień obecnych w przestrzeni społecznej - między innymi dotyczących przestępczości, w tym relacji dotyczących ofiar i sprawców.

Czytelnikom bliżej zainteresowanym tematyką tytułową można sugerować zapoznanie się z obszarami wiedzy kontekstualnie związanymi z winą i przebaczaniem, które ze względu na wymogi redakcyjne (objętość tekstu) zostały wprawdzie zasygnalizowane w koniecznym zakresie, ale już pełniej ich nie omawiano. Szczególnie chodzi o: „sumienie”, „dobro obiektywne”, „dobro nadrzędne”, ,sprawiedliwość”, ,godność człowieka”.

\section{Harm and Forgiveness in Social Rehabilitation and Other Aid Measures (Summary)}

The article deals with interpersonal relations emerging through crime. The issue of the harm caused to victims by offenders is presented in the context of the victims' forgiveness. The article points to different areas of interpersonal relations, where harm and forgiveness find their expression.

Key words: harm; trauma; forgiveness; social rehabilitation of offenders; therapeutic aid for victims. 


\section{Krzywda i przebaczenie w resocjalizacji i innych dzialaniach pomocowych (Streszczenie)}

W artykule odniesiono się do relacji interpersonalnych tworzonych przestępstwem. Zagadnienie krzywdy wyrządzanej ofiarom przez sprawców omówiono w kontekście ewentualności przebaczenia ze strony ofiar. Wykazano różne obszary relacji międzyludzkich, gdzie krzywda i przebaczenie znajdują swój wyraz.

Słowa kluczowe: krzywda; trauma; przebaczenie; resocjalizacja sprawców przestępstw; pomoc terapeutyczna ofiarom.

\section{Bibliografia}

Baron-Cohen, Simon. Teoria zła. Sopot: Smak Słowa, 2014.

Browne, Kevin, Martin Herbert. Zapobieganie przemocy w rodzinie. Warszawa: PARPA, 1999.

Gilligan, James. Wstyd i przemoc. Poznań: „Media i Rodzina”, 2001.

Hołyst, Brunon. Psychologia kryminalistyczna. Warszawa: Lexis Nexis, 2009.

Jasiński, Andrzej, Wojciech Zyzak, Aldona Król. „Przebaczenie”. W: Encyklopedia Katolicka, t. XVI, 604-606. Lublin: TN KUL, 2012.

Kmiecik-Baran, Krystyna. Młodzież i przemoc. Warszawa: PWN, 1999.

Konopczyński, Marek. „Kierunki zmian teorii i metodyki oddziaływań resocjalizacyjnych w Polsce". W: Wspótczesne kierunki zmian w teorii i praktyce resocjalizacyjnej, red. Marek Konopczyński, Wiesław Ambrozik, 7-63. Warszawa: CMPPP, 2009.

Kowalczyk, Stanisław. Wolność natura i prawem człowieka. Sandomierz: Wyd. Diecezjalne w Sandomierzu, 2000.

Majchrzyk, Zdzisław. Nieletni, młodociani, dorośli sprawcy zabójstw. Warszawa: IPiN, 2004.

Maultsby, Maxie C. Racjonalna Terapia Zachowania. Poznań: Alterna, 1992.

Nowak, Marian. Podstawy pedagogiki otwartej. Lublin: RW KUL, 2000.

Stein, Arndt. Kiedy dzieci sa agresywne. Warszawa: Jedność, 2002.

Szostek, Andrzej. Normy i wyjątki. Lublin: KUL, 1980.

Wach, Tomasz Janusz. Resocjalizacja nieletnich sprawców gwaltownych czynów zabronionych. Lublin: KUL, 2009. 
